\title{
WHISTLEBLOWER KASUS KORUPSI DAN UPAYA PERLINDUNGAN HUKUMNYA
}

\author{
Andreas Lumme \\ Universitas Atmajaya Makassar
}

\begin{abstract}
Abstrak
Masalah pokok dalam pembahasan ini adalah apakah undang-undang perlindungan saksi dan korban di Indonesia saat ini telah memberikan perlindungan hukum yang memadai berupa perlakuan khusus bagi pelapor (whistleblower) dan saksi pelaku yang bekerja sama (justice collaborators) dalam tindak pidana korupsi. Metode yang digunakan adalah pendekatan normatif, yang dipadukan dengan pendekatan praktik. Hasil pembahasan menunjukkan bahwa hukum positif Indonesia khususnya UU No.13 Tahun 2006 tentang Perlindungan Saksi dan Korban ternyata pelapor (whistleblower) dan saksi pelaku yang bekerja sama (justice collaborators) tindak pidana termasuk korupsi belum memperoleh pengaturan yang memadai, spesifik dan tegas. Kasus-kasus tindak pidana korupsi yang terjadi di Indonesia selama ini setelah berlakunya UU No.13 Tahun 2006, pelapor dan saksi pelaku yang bekerja sama belum mendapat perlindungan yang memadai. Masalah hubungan antara pemberdayaan sistem hukum (legal system) dan penegakan supremasi hukum (supremacy of law). Tujuan pembahasan yakni, menganalisis pelaksanaan penegakan supremasi hukum dan sistem hukum yang berlaku di Indonesia, serta kaitan antara penegakan supremasi hukum dan pemberdayaan sistem hukum. Metode pembahasan didasarkan atas analisis data sekunder (studi dokumen) yang meliputi peraturan perundang-undangan, buku-buku, jurnal-jurnal, berita di media masa dan dokumen lain yang relevan. Berdasarkan hasil penelitian ditemukan berbagai catatan buram penegakan supremasi hukum di Indonesia. Sikap dan perilaku warga masyarakat dan para pemimpin tidak mencerminkan prinsip supremasi hukum. Hal ini disebabkan oleh lemahnya ketiga pilar sistem hukum (Three Elements of Legal System) yang meliputi substansi hukum (legal substance), struktur hukum (legal structure) dan kultur hukum (legal culture). Karena itu maka pembenahan ketiga komponen sistem hukum merupakan tuntutan yang bersifat mutlak untuk dipenuhi (conditio sine quanon) demi tegaknya prinsip supremasi hukum.
\end{abstract}

Key words: supremasi hukum, perlindungan, pelapor, saksi, korupsi

\section{PENDAHULUAN}

Meningkatnya tindak pidana korupsi di Indonesia dengan berbagai modus operandi yang bersifat kolutif dan rahasia memerlukan penanganan yang luar biasa. Korupsi yang digolongkan sebagai extra ordinary crime telah menimbulkan ancaman yang serius terhadap sendi-sendi kehidupan masyarakat, nilai keadilan dan membahayakan supremasi hukum.

Dalam upaya meningkatkan partisipasi masyarakat untuk mengungkap tindak pidana korupsi harus diciptakan suasana yang memberikan kepastian berupa perlindungan hukumnya. Untuk menciptakan iklim yang kondusif dalam mengungkap tindak pidana korupsi, diperlukan instrumen-instrumen hukum yang memberikan kepastian hukum dan perlindungan hukum bagi setiap pengungkap atau pelapor kasus korupsi (whistleblower) dan saksi pelaku (justice collaborators) yang membantu penegak hukum untuk mengungkap tindak pidana korupsi. 
Instrumen hukum untuk memberikan perlindungan hukum bagi pelapor kasus korupsi dan saksi pelaku yang bekerja sama memegang peran penting dalam mengungkap tindak pidana korupsi. Banyak saksi dan pelapor yang enggan memberikan keterangan dalam proses peradilan karena mendapat intimidasi atau tekanan dari pihak-pihak yang tersangkut tindak pidana termasuk korupsi. Untuk memberikan rasa aman bagi saksi dan/atau pelapor perlu perlindungan, baik perlindungan fisik maupun perlindungan hukum.

Dalam berbagai kasus telah terjadi bahwa pelapor yang melaporkan tindak pidana korupsi dilapor balik dengan tuduhan pencemaran nama baik. Hal yang tragis lagi adalah laporan tentang pencemaran nama baik justeru lebih didahulukan proses peradilannya daripada laporan tindak pidana korupsi itu sendiri. Oleh karena itu, tanpa perlindungan yang memadai bagi pelapor (whistleblower) dan saksi pelaku yang bekerja sama (justice collaborators) sulit diharapkan mereka akan bersedia memberikan kesaksiannya.

Beberapa contoh kasus seperti Hamka Yandu dan Agus Condro merupakan saksi atau orang yang melaporkan penyimpangan yang terjadi dalam suatu lembaga, meskipun juga mereka tersandung dalam skandal tersebut. Keberadaan pelapor perlu landasan hukum yang memadai.

Di Indonesia, hukum perlindungan saksi dalam tindak pidana masih relatif baru. Meskipun telah dikenal sejak dikeluarkannya UU No.3 Tahun 1971 tentang Pemberantasan Tindak Pidana Korupsi, namun hanya mengarah pada perlindungan fisik. Melalui Kitab UndangUndang Hukum Acara Pidana (KUHAP) tahun 1981 juga dikenal perlindungan saksi, tetapi belum memperoleh kepastian implementasi dan juga masih terbatas pada perlindungan fisik.

Gagasan tentang perlunya perlindungan hukum terhadap saksi, khususnya dalam perkara korupsi mulai mengemuka pada tahun 1999. Sejak itu, beberapa elemen masyarakat mulai mengusulkan agar dipersiapkan undangundang tentang perlindungan saksi dalam proses peradilan pidana.

Selanjutnya, berdasarkan Ketetapan MPR Nomor VIII Tahun 2001 tentang Rekomendasi Arah Kebijakan Pemberantasan dan Pencegahan Korupsi, Kolusi dan Nepotisme diamanatkan agar undang-undang perlindungan saksi segera dibentuk. Tahun 2002, Badan Legislasi DPR RI mengajukan RUU Perlindungan Saksi dan Korban sebagai RUU usul inisiatif DPR.

Pada tahun 2003, Indonesia meratifikasi United Nations Convention Against Corruption. Dalam Pasal 32 dan 33 Konvensi tersebut disebutkan bahwa setiap negara peratifikasi wajib menyediakan perlindungan yang efektif terhadap saksi atau ahli dari pembalasan atau intimidasi termasuk keluarganya atau orang lain yang dekat dengan mereka.

Dengan dikeluarkannya UndangUndang No.31 Tahun 1999 tentang Pemberantasan Tindak Pidana Korupsi (UU PTPK) sebagaimana telah diubah dengan UU No.20 Tahun 2001, perlindungan saksi semakin mendapat perhatian. Meskipun demikian, perlindungan pelapor dan saksi kasus pidana termasuk korupsi masih memerlukan perbaikan/penyempurnaan untuk kepastian implementasi.

Pelapor dan saksi pelaku yang bekerja sama dalam tindak pidana korupsi perlu instrumen hukum yang memberikan perlindungan memadai dan kepastian hukum untuk implementasinya. Adanya perlindungan hukum berupa perlakuan khusus bagi setiap pelapor dan saksi pelaku yang bekerja sama akan memudahkan penegak hukum mengungkap tindak pidana korupsi.

Berdasarkan hal-hal yang telah diuraikan di atas, maka rumusan masalah dalam pembahasan ini adalah sebagai berikut: Apakah undang-undang perlindungan saksi dan korban yang ada saat ini telah memberikan perlindungan hukum yang memadai berupa perlakuan khusus bagi pelapor (whistleblower) dan saksi pelaku yang bekerja sama (justice 
collaborators) dalam tindak pidana khusus termasuk korupsi?

\section{METODE PEMBAHASAN}

Metode yang digunakan dalam pembahasan ini adalah meneliti bahanbahan pustaka atau data sekunder. Pendekatan yang digunakan adalah pendekatan normatif, yaitu dari sisi normanorma hukum yang berlaku bagi saksi dan korban serta pelapor dalam rangka proses peradilan tindak pidana termasuk korupsi.

Data sekunder yang dikumpulkan dari hasil penelitian buku-buku dan peraturan perundang-undangan yang ada relevansinya dengan perlindungan saksi dan pelapor tindak pidana korupsi. Data yang berhasil dikumpulkan dianalisis secara kualitatif, kemudian diuraikan secara deskriptif dalam pembahasan.

\section{SIFAT PERLINDUNGAN DAN SUBJEK YANG MENDAPAT PERLIN-DUNGAN DALAM TINGKATAN UNDANG- UNDANG}

Perlindungan hukum bagi pelapor dan saksi diperlukan mengingat dalam tindak pidana khusus seperti korupsi sering mendapat ancaman baik langsung maupun tidak langsung. Menurut Pasal 1 angka 4 UU No.13 Tahun 2006 tentang Perlindungan Saksi dan Korban, ancaman adalah segala bentuk perbuatan yang menimbulkan akibat, baik langsung maupun tidak langsung, yang mengakibatkan saksi dan/atau korban merasa takut dan/atau dipaksa untuk melakukan atau tidak melakukan sesuatu hal yang berkenaan dengan pemberikan kesaksiannya dalam suatu proses peradilan pidana.

Dengan meneliti lebih lanjut UU No.13 Tahun 2006 tentang Perlindungan Saksi dan Korban maka tampak bahwa perlindungan terhadap saksi dan korban bersifat terbatas. Bersifat terbatas karena perlindungan hanya diberikan untuk proses peradilan pidana, bukan untuk peradilan perdata, peradilan agama, peradilan tata usaha negara dan peradilan militer. Meskipun demikian, perlindungan saksi dan korban diberikan menyeluruh mulai dari proses penyelidikan, penyidikan, penuntutan, pengadilan (pengadilan pertama, banding, kasasi dan peninjauan kembali) sampai dengan pemenjaraan. Perlindungan juga diberikan untuk pelapor, tetapi untuk pelapor masih sangat sumir.

Menurut Pasal 1 angka 6 UU No.13 Tahun 2006 tentang Perlindungan Saksi dan Korban), perlindungan adalah segala bentuk upaya pemenuhan hak dan pemberian bantuan untuk memberikan rasa aman kepada saksi dan/atau korban yang wajib dilaksanakan oleh Lembaga Perlindungan Saksi dan Korban (LPSK) atau lembaga lainnya sesuai dengan ketentuan UndangUndang ini.

Pengertian saksi sebagaimana dirumuskan dalam Pasal 1 angka 1 UU No.13 Tahun 2006 tentang Perlindungan Saksi dan Korban, adalah orang yang dapat memberikan keterangan guna kepentingan penyelidikan, penyidikan, penuntutan, dan pemeriksaan di sidang pengadilan tentang suatu perkara pidana yang ia dengar sendiri, ia lihat sendiri, dan/atau ia alami sendiri. Rumusan yang relatif sama dengan Pasal 1 angka 26 UU No.8 Tahun 1981 tentang KUHAP, yaitu saksi adalah orang yang dapat memberikan keterangan guna kepentingan penyelidikan, penyidikan, penuntutan, dan pemeriksaan di sidang pengadilan tentang suatu perkara pidana yang ia dengar sendiri, ia lihat sendiri dan ia alami sendiri. Selanjutnya, Pasal 1 angka 27 UU No.8 Tahun 1981 tentang KUHAP mengatur tentang keterangan saksi sebagai salah satu alat bukti dalam perkara pidana yang berupa keterangan dari saksi mengenai suatu peristiwa pidana yang ia dengar sendiri, ia lihat sendiri dan ia alami sendiri dengan menyebut alasan dari pengetahuannya itu.

Dalam Pasal 9 UU No.13 Tahun 2006 tentang Perlindungan Saksi dan Korban ditentukan bahwa: 
1. Saksi dan/atau korban yang merasa dirinya berada dalam ancaman yang sangat besar, atas persetujuan hakim dapat memberikan kesaksian tanpa hadir langsung di pengadilan tempat perkara tersebut sedang diperiksa.

2. Saksi dan/atau korban tersebut dapat memberikan kesaksian secara tertulis yang disampaikan di hadapan pejabat yang berwenang dan membubuhkan tanda tangannya pada berita acara yang memuat tentang kesaksian tersebut.

3. Saksi dan/atau korban tersebut dapat pula didengar kesaksiannya secara langsung melalui sarana elektronik dengan didampingi oleh pejabat yang berwenang.

Antara saksi dan pelapor dibedakan sebagaimana ditemukan dalam Pasal 10 UU No.13 Tahun 2006. Penjelasan pasal tersebut menyatakan bahwa "pelapor" adalah orang yang memberikan informasi kepada penegak hukum mengenai terjadinya suatu tindak pidana.

Di samping itu, dalam Pasal $31 \mathrm{UU}$ No.31 Tahun 1999 tentang Pemberantasan Tindak Pidana Korupsi, dirumuskan sebagai berikut:

1. Dalam penyidikan dan pemeriksaan di sidang pengadilan, saksi dan orang lain yang bersangkutan dangan tindak pidana korupsi dilarang menyebut nama atau alamat pelapor, atau hal-hal lain yang memberikan kemungkinan dapat diketahuinya identitas pelapor.

2. Sebelum pemeriksaan dilakukan larangan tersebut diberitahukan kepada saksi dan orang lain tersebut.

Dalam penjelasannya dirumuskan bahwa yang dimaksud dengan "pelapor" adalah orang yang memberi informasi kepada penegak hukum mengenai terjadinya suatu tindak pidana korupsi dan bukan pelapor sebagaimana dimaksud dalam Pasal 1 angka 24 UU No.8 Tahun 1981 tentang KUHAP.

Selanjutnya, pengaturan pelapor ditemukan juga dalam PP No.71 Tahun 2000 tentang Tata Cara Pelaksanaan Peran Serta Masyarakat dan Pemberian Penghargaan Dalam Pencegahan dan
Pemberantasan Tindak Pidana Korupsi. Pasal 2 PP No.71 Tahun 2000 menyatakan:

1. Setiap orang, Organisasi Masyarakat, atau Lembaga Swadaya Masyarakat berhak mencari, memperoleh, dan memberikan informasi adanya dugaan telah terjadi tindak pidana korupsi serta menyampaikan saran dan pendapat kepada penegak hukum dan atau Komisi mengenai perkara tindak pidana korupsi.

2. Penyampaian informasi, saran, dan pendapat atau permintaan informasi harus dilakukan secara bertanggung jawab sesuai dengan ketentuan peraturan prundang-undangan yang berlaku, norma agama, kesusilaan, dan kesopanan.

Menurut Penjelasan Pasal 3 ayat (1) PP No.71 Tahun 2000, yang dimaksud dengan "pelapor" adalah orang yang memberi suatu informasi kepada penegak hukum atau Komisi mengenai terjadinya suatu tindak pidana korupsi dan bukan pelapor sebagaimana dimaksud dalam Pasal 1 angka 24 UU No.8 Tahun 1981 tentang KUHAP.

Dengan memperhatikan rumusan Pasal 31 UU No.31 Tahun 1999 dan penjelasannya serta Peratura Pemerintah di atas maka ketentuan tersebut tidak memberikan perlindungan hukum kepada saksi dan pelapor. Pada Pasal 15 UU No.30 Tahun 2002 tentang Komisi Pemberantasan Korupsi dan penjelasannya ditentukan bahwa Komisi Pemberantasan Korupsi (KPK) berkewajiban memberikan perlindungan terhadap saksi dan pelapor mengenai terjadinya tindak pidana korupsi. Perlindungan yang diberikan kepada saksi dan pelapor itu hanya perlindungan yang bersifat fisik, yaitu keamanan dan perubahan identitas. Belum ada norma untuk perlakuan khusus atas perlindungan hukum bagi pihak-pihak yang terlibat dalam perkara tindak pidana korupsi.

Saksi pelapor telah lasim disebut dengan whistleblower. Menurut Indriyanto Seno Adji (2009: 409), whistleblower merupakan makna kriminologis bagi mereka yang memiliki keberanian membongkar 
suatu kejahatan yang berada di lingkungan kehidupan, profesi maupun lingkungan sosialnya. Whistleblower diartikan diartikan "peniup peluit" yang dalam perkembangannya secara kriminologis dimaknai sebagai pelaku kriminal yang membongkar kejahatan. Aneh memang terdengar, tetapi itulah fenomena kriminal yang solusif. Polemik terjadi manakala ada introdusir untuk memperkenalkan suatu kolaborasi antara pelaku criminal dengan penegak hukum, yang kemudian dikenal sebagai whistleblower. Peran inner-circle criminal dianggap memiliki daya potensial untuk membuka tabir kejahatan lebih signifikan. Namun demikian, sebagai suatu balanced of bargain terhadap pelaku tersebut diberikan suatu reward berupa perlindungan hukum yang dinamakan protection of cooperating person, baik itu person diartikan sebagai saksi (witness), korban (victim) maupun pelapor (reporter).

Komnas HAM Perempuan (2009:

17) berpendapat bahwa pembedaan antara saksi dan pelapor tidak dijelaskan dengan rinci dalam penjelsan UU No.13 Tahun 2006 tentang Perlindungan Saksi dan Korban. Mengenai saksi pelapor untuk mendapatkan perlindungan hukum juga tidak dijelaskan secara rinci bentuk dan prosedurnya. Dengan kondisi demikian, terbuka kemungkinan terjadinya praktik perlindungan yang lebih "mementingkan" para pelaku daripada para saksi maupun korban, terutama tidak diaturnya secara terperinci hak-hak para saksi dan korban untuk memperoleh perlindungan dan dukungan.

Pada Pasal 10 ayat (1) dan (2) UU No.13 Tahun 2006 diatur tentang:

- Saksi, korban dan pelapor tidak dapat dituntut secara hukum baik pidana maupun perdata atas laporan, kesaksian yang akan, sedang, atau telah diberikannya.

- Seorang saksi yang juga tersangka dalam kasus yang sama tidak dapat dibebaskan dari tuntutan pidana apabila ia ternyata terbukti secara sah dan meyakinkan bersalah, tetapi kesaksiannya dapat dijadikan pertimbangan hakim dalam meringankan pidana yang akan
dijatuhkan.

Dari rumusan yang disebut terakhir tampak bahwa dasar hukum pelapor dalam tindak pidana termasuk korupsi belum memperoleh pengaturan yang memadai. Kasus-kasus pelapor tindak pidana korupsi yang terjadi di Indonesia setelah berlakunya UU No.13 Tahun 2006 belum mendapat perlindungan yang memadai.

Menurut Laporan Utama Majalah Kesaksian: Media Informasi Perlindungan Saksi dan Korban (Edisi I 2011), UU No.13 Tahun 2006 diundangkan pada saat Indonesia belum memiliki pengalaman yang cukup dalam memberikan perlindungan terhadap saksi, korban dan pelapor.

Muhadar, dkk (2010: 5-6) mengemukakan bahwa saksi pelapor merupakan saksi yang berasal dari orang yang berkepentingan dengan kasus yang terjadi maupun yang tidak. Oleh karena itu, terkadang bukannya mendapat pujian, tetapi sering membuat saksi menjadi target pengancaman bahkan pembunuhan dari orang-orang yang merasa dengan

keterangan saksi nantinya akan menjerumuskan tersangka/terdakwa ke dalam penjara. Permasalahannya, saksi dalam perundang-undangan Indonesia belum mendapat perhatian yang besar terhadap perlindungan saksi.

Lebih lanjut Muhadar, dkk (2010:

100) mengemukakan bahwa UU perlindungan saksi dan korban melupakan orang yang memberikan bantuan kepada aparat penegak hukum untuk keterangan dan membantu proses pemeriksaan pidana yang berstatus ahli dengan keahlian khusus.

Hal senada ditegaskan oleh Gayus Lumbuun (2011: 12-13) bahwa revisi terhadap UU No.13 Tahun 2006 harus mempertegas kewenangan Lembaga Perlindungan Saksi dan Korban dan Pelapor sebagai satu-satunya yang berwewenang untuk melakukan tindakan perlindungan. Kasus Susno Duadji yang tidak dapat dilindungi oleh LPSK menggambarkan bahwa UU No.13 Tahun 2006 belum 
memiliki kerangka pengaturan yang komprehensif, integratif, dan detail atau spesifik terhadap kepentingan pelapor. UU tersebut belum mampu menjadi satu-satunya payung hukum sebagai dasar bagi penyelenggaraan saksi dan korban, serta pelapor karena masih mengacu kepada peraturan perundang-undangan lain, yaitu menjadi kewenangan kepolisian.

$$
\text { Selanjutnya, Gayus Lumbuun }
$$

(2011: 13-14) mengemukakan bahwa argumentasi revisi terhadap UU No.13 Tahun 2006 dapat dijelaskan dalam 3 kerangka argumentasi, yaitu:

- secara filosofis, UU No.13 Tahun 2006 masih diperlukan upaya untuk menciptakan rasa aman dan nyaman bagi semua warga masyarakat;

- secara sosiologis, terdapat banya pelapor yang masih menjadi korban intimidasi, mendapatkan anaman, bahkan penganiayaan serta kesulitan bagi LPSK untuk melakukan perlindungan;

- secara yuridis, peraturan ini memiliki kekurangan yaitu belum menjadi satu dasar hukum yang komprehensif bagi penyelenggaraan perlindungan saksi, korban, dan pelapor dalam sistem peradilan pidana, karena ternyata ada peraturan perundang-undangan yang tingkatannya lebih randah justru menjadi acuan.

Menyadari kekurangan UU No.13

Tahun 2006, Mahkamah Agung RI mengeluarkan Surat Edaran Nomor 04 Tahun 2011 tentang Perlakuan Bagi Pelapor Tindak Pidana (Whistleblower) dan Saksi Pelaku yang Bekerjasama (Justice Collaborators) di Dalam Tindak Pidana Tertentu. Melalui Surat Edaran tersebut Mahkamah Agung RI menyatakan antara lain:

1. Meminta kepada para hakim jika menemukan tentang adanya orang-orang yang dapat dikategorikan sebagai Pelapor Tindak Pidana dan Saksi Pelaku yang Bekerjasama dapat memberikan perlakuan khusus dengan antara lain memberikan keringanan pidana dan/atau bentuk perlindungan lainnya;
2. Pedoman-pedoman yang harus ditaati dalam penanganan kasus yang melibatkan Pelapor Tindak Pidana (Whistleblower) adalah sebagai berikut:

a. Yang bersangkutan merupakan pihak yang mengetahui dan melaporkan tindak pidana tertentu sebagaimana dimaksud dan SEMA ini dan bukan merupakan bagian dari pelaku kejahatan yang dilaporkannya;

b. Apabila Pelapor Tindak Pidana dilaporkan pula oleh terlapor, maka penanganan perkara atas laporan yang disampaikan oleh Pelapor Tindak Pidana didahulukan dibanding laporan dari terlapor.

3. Pedoman untuk menentukan seseorang sebagai Saksi Pelaku yang Bekerjasama (Justice Collaborators) adalah sebagai berikut:

a. Yang bersangkutan merupakan salah satu pelaku tindak pidana tertentu sebagaimana dimaksud dalam SEMA ini, mengakui kejahatan yang dilakukannya, bukan pelaku utama dalam kejahatan tersebut serta memberikan keterangan sebagai saksi di dalam proses peradilan;

b. Jaksa Penuntut Umum di dalam tuntutannya menyatakan bahwa yang bersangkutan telah memberikan keterangan dan bukti-bukti yang sangat signifikan sehingga penyidik dan/atau penuntut umum dapat mengungkap tindak pidana dimaksud secara efektif, mengungkap pelakupelaku lainnya yang memiliki peran lebih besar dan/atau mengembalikan asset-aset/hasil suatu tindak pidana;

c. Atas bantuan tersebut, maka terhadap Saksi Pelaku yang Bekerjasama sebagaimana dimaksud di atas, hakim dalam menentukan pidana yang akan diajatuhkan dapat mempertimbangkan hal-hal penjatuhan pidana sebagai berikut:

- menjatuhkan pidana percobaan bersyarat khusus, dan/atau

- menjatuhkan pidana berupa pidana penjara yang paling ringan di antara terdakwa lainnya yang 
terbukti bersalah dalam perkara yang dimaksud.

Dalam memberikan perlakuan khusus dalam bentuk keringanan pidana hakim tetap wajib mempertimbangkan rasa keadilan masyarakat.

d. Ketua Pengadilan di dalam mendistribusikan perkara memperhatkan hal-hal sebagai berikut:

- memberikan perkara-perkara terkait yang diungkap Saksi Pelaku yang Bekerjasama kepada majelis yang sama sejauh memungkinkan; dan

- mendahulukan perkara-perkara lain yang diungkap oleh Saksi Pelaku yang Bekerjasama.

Dengan adanya Surat Edaran Mahkamah Agung tersebut paling tidak telah dapat mengisi kekurangan atau kekosongan hukum mengenai perlindungan pelapor dan saksi pelaku yang bekerja sama dalam peradilan pidana termasuk pidana korupsi. Sema tersebut dapat berfungsi sebagai sumber hukum bagi para penegak hukum khususnya hakim di dalam menyelesaikan perkara-perkara yang berkenaan dengan pelapor dan saksi pelaku yang bekerja sama. Akan tetapi, materi perlakuan khusus dalam Surat Edaran Mahkamah Agung tersebut harus diadopsi ke dalam undang-undang agar lebih mempunyai kekuatan mengikat secara publik.

\section{PERANAN LEMBAGA PERLINDUNGAN SAKSI DAN KORBAN SECARA NORMATIF DAN PRAKTIK}

Lembaga Perlindungan Saksi dan Korban (LPSK) yang telah dibentuk sekitar 3 tahun yang lalu sejak tanggal 8 Agustus 2008. LPSK adalah lembaga yang mandiri, namun bertanggung jawab kepada Presiden. Muhadar, dkk (2010: 206) mengemukakan bahwa yang dimaksud mandiri adalah sebuah lembaga yang independen, yakni organ negara yang diidealkan independen dan karenanya berada di luar cabang kekuasaan baik eksekutif, legislative maunpun yudikatif, namun memiliki fungsi campuran antar ketiga cabang kekuasaan tersebut.

UU Perlindungan Saksi dan Korban tersebut tidak secara spesifik mengenai tugas, kewenangan dan kewajibannya. Namun demikian, jika diteliti maka tugas, kewenangan LPSK tersebar dalam berbagai Pasal, yang intinya dapat dirangkum sebagai berikut:

- Menerima permohonan saksi dan/atau korban untuk memperoleh perlindungan;

- Memberikan perlindungan dan hak-hak lain kepada saksi dan/atau korban;

- Mengeluarkan keputusan pemberian perlindungan saksi dan/atau korban;

- Mengajukan ke pengadilan berupa: hak atas kompensasi dalam kasus pelanggaran hak asasi manusia yang berat dan hak atas restitusi atau ganti kerugian yang menjadi tanggung jawab pelaku tindak pidana;

- Menerima permintaan tertulis dari korban ataupun orang yang mewakili korban untuk bantuan;

- Menentukan kelayakan diberikannya bantuan kepada saksi dan/atau korban, jangka waktu dan besaran biaya yang diperlukan;

- Dalam melaksanakan pemberian perlindungan dan bantuan, LPSK dapat bekerja sam dengan instansi terkait yang berwewenang.

Menurut Laporan Utama Majalah Kesaksian: Media Informasi Perlindungan Saksi dan Korban (Edisi I 2011), memasuki usia ke-3, LPSK kerap mengalami kendala dan hambatan dalam pelaksanaan UU Perlindungan Saksi dan Korban tersebut. Hal ini terkait kewenangan LPSK dalam penanganan pemberian perlindungan, penyempurnaan pemenuhan hak saksi dan korban terutama dalam hal pendampingan, mekanisme pemberian restitusi dan kompensasi dan terkait kedudukan serta kelembagaan LPSK. 
Untuk pengisian anggota LPSK, Pasal 14 UU No.13 Tahun 2006 tentang Perlindungan Saksi dan Korban mengatur bahwa anggota LPSK terdiri atas 7 orang yang berasal dari unsur profesional yang mempunyai pengalaman di bidang pemajuan, pemenuhan, perlindungan, penegakan hukum dan hak asasi manusia, kepolisian, kejaksaan, Departemen Hukum dan Hak Asasi Manusia, akademisi, advokat, atau lembaga swadaya masyarakat. Masa jabatan anggota LPSK adalah 5 tahun. Setelah berakhir masa jabatannya, anggota LPSK dapat dipilih kembali dalam jabatan yang sama, hanya untuk 1 kali masa jabatan berikutnya.

Pengangkatan anggota LPSK diatur pada Pasal 23 UU No.13 Tahun 2006 tentang Perlindungan Saksi dan Korban sebagai berikut:

1. Anggota LPSK diangkat oleh Presiden dengan persetujuan Dewan Perwakilan Rakyat.

2. Untuk dapat diangkat menjadi anggota LPSK harus memenuhi syarat:
a. warga Negara Indonesia;
b. sehat jasmani dan rohani;
c. tidak pernah dijatuhi pidana karena melakukan tindak pidana kejahatan yang ancaman pidananya paling singkat 5 tahun;
d. berusia paling rendah 40 tahun dan paling tinggi 65 tahun pada saat proses pemilihan;

e. berpendidikan paling rendah $\mathrm{S}-1$;

f. berpengalaman di bidang hukum dan hak asasi manusia paling singkat 10 tahun;

g. memiliki integritas dan kepribadian yang tidak tercela; dan

h. memiliki nomor pokok wajib pajak.

Menurut Pasal 24 UU No.13 Tahun

2006 tentang Perlindungan Saksi dan Korban, anggota LPSK diberhentikan karena:

a. meninggal dunia;

b. masa tugasnya telah berakhir;

c. atas permintaan sendiri;

d. sakit jasmani atau rohani yang mengakibatkan tidak menjalankan tugas selama 30 hari secara terus menerus; e. melakukan perbuatan tercela dan/atau hal-hal lain yang berdasarkan Keputusan LPSK yang bersangkutan harus diberhentikan karena telah mencemarkan martabat dan reputasi, dan/atau mengurangi kemandirian dan kredibilitas LPSK; atau

f. dipidana karena bersalah melakukan tindak pidana kejahatan yang ancaman pidananya paling singkat 5 tahun.

Dalam mewujudkan efektivitas perlindungan saksi dan korban, LPSK dan Kejaksaan Agung telah membuat Nota Kesepahaman Nomor: NK003/1.6/LPSK/IV/ 2011 tanggal 20 April 2011. Ruang lingkup Nota Kesepahaman tersebut meliputi:

- menangani permohonan perlindungan saksi dan korban dalam kasus korupsi, terorisme, narkotika dan pelanggaran HAM yang berat dan tindak pidana lain yang mengakibatkan posisi saksi dan korban dihadapkan pada situasi yang sangat membahayakan jiawanya;

- melakukan perlindungan saksi, korban, dan pelapor;

- memberikan dukungan kepada korban dalam proses kompensasi, restitusi, ganti kerugian dan bantuan medis dan psikososial;

- menjaga aspek kerahasiaan dalam aktivitas perlindungan saksi dan korban, meliputi aspek administrasi dan pelaksanaan teknis;

- menyelenggarakan sosialisasi dalam aktivitas perlindungan saksi dan korban;

- memberikan bantuan hukum dan pertimbangan hukum dalam penyelesaian sengketa

di bidang perdata dan tata usaha negara di lingkungan LPSK;

- mengembangkan kapasitas kelembagaan dan kemampuan personil dalam aktivitas perlindungan saksi dan korban.

Dalam praktik, LPSK mulai memperlihatkan perannya dalam beberapa kasus korupsi. Dalam Kompas.Com (2011) dikemukakan bahwa LPSK menurunkan tim ke Manado, Sulawesi Utara untuk melindungi Stanli Ering, pemberi informasi 
(whistleblower) kasus dugaan korupsi penyalahgunaan dana penelitian dan pembangunan gedung laboratorium Universitas Manado. Laporan Stanli berbuah menjadi ancaman terhadap dirinya sebagai pelapor kasus korupsi. Stanli kini menjadi terdakwa kasus pencemaran nama baik. Kasus ini dinilai sebagai serangan balik terhadap Stanli selaku whistleblower kasus korupsi. LPSK telah mendampingi Stanli dalam siding yang digelar pada hari ini dalam kasus dugaan pencemaran nama baik. LPSK juga akan mendampingi Stanli dalam pemeriksaan kejaksaan atas laporan dugaan korupsi yang dilakukan Rektor Universitas Manado.

\section{SYARAT DAN TATA CARA PEMBERIAN PERLINDUNGAN DALAM UNDANG-UNDANG PERLINDUNGAN SAKSI DAN KORBAN}

Instrumen hukum tentang perlindungan saksi dan korban seharusnya memberikan perlindungan dan bantuan yang memadai sehingga merasa aman, baik secara fisik maupun secara yuridis. Untuk mengimplementasikan perlindungan itu, maka hak-hak seorang saksi dan korban telah diatur dalam Pasal 5 ayat (1) UU No.13 Tahun 2006, sebagai berikut:

a. memperoleh perlindungan dan keamanan pribadi, keluarga, dan harta bendanya, serta bebas dari ancaman yang berkenaan dengan kesaksian yang akan, sedang, atau telah diberikannya;

b. ikut serta dalam proses memilih dan menentukan bentuk perlindungan dan dukungan keamanan;

c. memberikan keterangan tanpa tekanan;

d. mendapat penerjemah;

e. bebas dari pertanyaan yang menjerat;

f. mendapatkan informasi mengenai putusan pengadilan;

g. mengetahui dalam hal terpidana dibebaskan;

h. mendapat identitas baru;

i. mendapatkan tempat kediaman baru; j. memperoleh penggantian biaya transportasi sesuai dengan kebutuhan;

k. mendapat nasihat hukum; dan/atau

1. memperoleh bantuan biaya hidup sementara sampai batas waktu perlindungan berakhir.

Hak-hak di atas menurut UU No.13

Tahun 2006, hanya diberikan kepada saksi dan/atau korban tindak pidana dalam kasuskasus tertentu sesuai dengan Keputusan LPSK. Dirumuskan dalam Penjelasan Pasal 5 ayat (2) UU tersebut bahwa yang dimaksud "kasus-kasus tertentu", antara lain, tindak pidana korupsi, tindak pidana narkotika/psikotropika, tindak pidana terorisme, dan tindak pidana lain yang mengakibatkan posisi saksi dan korban dihadapkan pada situasi yang sangat membahayakan jiwanya.

Menurut Pasal 28 UU No.13 Tahun 2006 tentang Perlindungan Saksi dan Korban, perjanjian perlindungan LPSK terhadap saksi dan/atau korban tindak pidana dengan mempertimbangkan syarat sebagai berikut:

a. sifat pentingnya keterangan saksi dan/atau korban;

b. tingkat ancaman yang membahayakan saksi dan/atau korban;

c. hasil analisis tim medis atau psikolog terhadap saksi dan/atau korban;

d. rekam jejak kejahatan yang pernah dilakukan oleh saksi dan/atau korban. Indriyanto Seno Adji (2009: 407) mengenukakan bahwa kriteria atau syarat di atas perlu untuk menghindari adanya penyimpangan terhadap program perlindungan dijadikan sarana penampungan pelaku victimless crimes, bahkan kejahatan yang bersifat jobless.

Tata cara memperoleh perlindungan diatur pada Pasal 29 UU No.13 Tahun 2006 tentang Perlindungan Saksi dan Korban sebagai berikut:

a. Saksi dan/atau korban yang bersangkutan, baik atas insiatif sendiri maupun atas permintaan pejabat yang berwewenang, mengajukan permohonan secara tertulis kepada LPSK;

b. LPSK segera melakukan permeriksaan terhadap permohonan tersebut; 
c. Keputusan LPSK diberikan secara tertulis paling lambat 7 hari sejak permohonan perlindungan diajukan.

Selanjutnya, Pasal 30 UU No.13

Tahun 2006 tentang Perlindungan Saksi dan

Korban mengatur hal-hal sebagai berikut:

1. Dalam hal LPSK menerima permohonan saksi dan/atau korban, saksi dan/atau korban menandatangani pernyataan kesediaan mengikuti syarat dan ketentuan perlindungan saksi dan korban.

2. Pernyataan kesediaan mengikuti syarat dan ketentuan perlindungan saksi dan korban memuat:

a. kesediaan saksi dan/atau korban untuk memberikan kesaksian dalam proses peradilan;

b. kesediaan saksi dan/atau korban untuk menaati aturan yang berkenaan dengan keselamatannya;

c. kesediaan saksi dan/atau korban untuk tidak berhubungan dengan cara apa pun dengan orang lain selain atas persetujuan LPSK, selama ia berada dalam perlindungan LPSK;

d. kewajiban saksi dan/atau korban untuk tidak memberitahukan kepada siapa pun mengenai keberadaannya di bawah perlindungan LPSK; dan

e. hal-hal lain yang dianggap perlu oleh LPSK.

Pasal 37 United Nations Convention Against Corruption antara lain mengatur sebagai berikut:

- Setiap negara peserta wajib mempertimbangkan, memberikan kemungkinan dalam kasus-kasus tertentu mengurangi hukuman dari seorang pelaku memberikan kerja sama yang substansial dalam penyidikan atau penuntutan suatu kejahatan yang ditetapkan berdasarkan konvensi ini.

- Setiap negara peserta wajib mempertimbangkan kemungkinan sesuai dengan prinsip-prinsip dasar hukum nasionalnya untuk memberikan kekebalan dari penuntutan bagi orang yang memberikan kerja sama substansial dalam penyidikan atau penuntutan suatu tindak pidana yang ditetapkan berdasarkan konvensi ini.
Sebenarnya dengan diratifikasinya Konvensi PBB Mengenai Korupsi, 2003 (United Nations Convention Against Corruption, 2003) oleh Indonesia, maka perlindungan hukum pelapor (whistleblower) dan saksi pelaku yang bekerja sama (justice collaborators) dalam tindak pidana korupsi, seharusnya telah spesifik diatur dalam undang-undang.

\section{KESIMPULAN}

Berdasarkan hasil pembahasan di atas maka beberapa hal yang dapat disimpulkan sebagai berikut:

1. Hukum positif Indonesia khususnya UU No.13 Tahun 2006 tentang Perlindungan Saksi dan Korban membedakan saksi dan pelapor. Menurut undang-undang tersebut "pelapor" adalah orang yang memberikan informasi kepada penegak hukum mengenai terjadinya suatu tindak pidana. Namun demikian, dasar hukum tersebut pelapor tindak pidana termasuk korupsi belum memperoleh pengaturan yang memadai, spesifik dan tegas. Kasus-kasus tindak pidana korupsi yang terjadi di Indonesia selama ini termasuk setelah berlakunya UU No.13 Tahun 2006, pelapor (whistleblower) belum mendapat perlindungan yang memadai.

2. Meskipun Indonesia telah meratifikasi Konvensi PBB Mengenai Korupsi, 2003 (United Nations Convention Against Corruption, 2003), perlindungan hukum berupa perlakuan khusus bagi pelapor (whistleblower) dan saksi pelaku yang bekerja sama (justice collaborators) dalam tindak pidana khusus termasuk korupsi, seharusnya spesifik dan tegas diatur dalam undang-undang. 


\section{DAFTAR PUSTAKA}

http://www1.kompas.com. 9 November 2011. LPSK Lindungi "Whistle Blower" Korupsi di Manado. diunduh 17 November 2011.

Komnas Perempuan. 2009. Perlindungan Terhadap Saksi dan Korban. Penerbit: Komnas Perempuan Jakarta.

Lumbuun, Gayus. 2011. Perlindungan Terhadap Pelapor Dalam Sistem Peradilan Pidana di Indonesia. Majalah Media Informasi Perlindungan Saksi dan Korban Edisi I Tahun 2011 Halaman 1015. Penerbit: LPSK.

Thalib, H., \& Poernomo, P. P. D. H. B. 2002. Kebijakan sanksi pemidanaan dalam penyelesaian konflik pertanahan di luar kodifikasi hukum pidana. (Doctoral dissertation, Universitas Gadjah Mada).

Thalib, H. 2012. Sanksi Pemidanaan Dalam Konflik Pertanahan. Kencana.

Muhadar, dkk. 2010. Perlindungan Saksi \& Korban Dalam Sistem Peradilan Pidana. Penerbit: Putra Media Nusantara Surabaya.

Muhsoni, M. Hasyim. 2011. Menatap Revisi UU No.13 Tahun 2006. Majalah Media Informasi Perlindungan Saksi dan Korban Edisi I Tahun 2011 Halaman 2729. Penerbit: LPSK.
Seno Adji, Indriyanto. 2009. Korupsi dan Penegakan Hukum. Penerbit: Diadit Media Jakarta. 